\title{
Administrative Procedure in Albania
}

\author{
Pranvera Xhafaj \\ (PhD Candidate at Tirana European University), Tirana, Albania \\ veraxhafaj@gmail.com
}

\section{Doi:10.5901/mjss.2015.v6n1s1p438}

\begin{abstract}
The court and the parties constitute the core of administrative procedural legal relations, but besides them, third persons can also participate in these relations, who are part of litigation, such as the bailiff in the execution phase and when this process becomes part of the trial process on complaint. They conduct procedural actions with the active participation, in accordance with administrative procedural norms, influencing the "course, development and completion of the trial". This paragraph shall constitute the purpose and objectives of this paper. In administrative procedural relations attend some subjects who carry certain procedural rights and duties provided by applicable law. The main subject in this relation is the court because of its crucial role in the development of these administrative relations. The Court has a leading and unique position because it is only the court which has the right to resolves an administrative issue giving the final decision. This stems from the fact that the court is the only body authorized by law to administer justice and as such it binding participates in all relations arising during the trial of cases (Adv. N.Uka, Adv. J.Brati "Magistracy \& Advocacy", "ILARI" P.F., Tirana, 2012, p. 454.) The methodology used is qualitative comparative of the two main doctrines on administrative procedure: Years of dictatorship (1962) and nowadays (2012). This paper will serve to other studies of the field ongoing since the Administrative Court is a new court in the Republic of Albania. And for that fact, books or publications in this field are few in number in Albania.
\end{abstract}

Keywords: court, legal relations, administrative procedure, administrative subject.

\section{The Meaning of Administrative Procedural Legal Relations}

The court and the litigants are the main subjects in an administrative procedural relations. These subjects as active party (plaintiff, petitioner) but also passive (the defendant, the third person, the person concerned) may perform procedural actions in accordance with administrative procedural norms affecting directly but also indirectly the initiation, development and completion of a concrete trial.

It is impossible to have administrative procedural legal relation without the existence of a lawsuit filed for judicial review. Subjects who interfere in this administrative procedural legal relation interfere or are forced to interfere only within the judicial process which is initiated by lawsuit. Administrative legal relation does not depend on administrative judicial process since it is realized regardless of the judicial process and outside the judicial process as a separate relation in an independent court and not as part of its section.

Administrative procedural legal relation is realized within the judicial process or within the trial. There are other persons who participate in the judicial process such as the court record holder held by judicial secretariat, representatives of the litigants, the state advocacy as a party that defends the interests of the parties at trial, witnesses, experts and translators, but these are not direct subjects of administrative judicial process because with their participation they do not have the same impact as the litigants because they actually have only an auxiliary role in the actions of the subjects of the process.

Administrative procedural legal relation is broader than the administrative judicial process. In order to understand the administrative procedural legal relation there are given different definitions trying to incorporate its basic elements. But in general it can be said that the administrative procedural legal relation is the specific relation between the court and other procedural subjects, who are associated with certain procedural rights and duties of administrative procedural law norms.

Procedural legal relation is the entirety of the rights and duties of the subjects participating in the judicial process with opposing parties, in the administrative judicial process. 


\section{Subjects of Administrative Procedural Legal Relations}

In the administrative adjudication in the development and resolution of administrative issue participate the court, litigants, in some cases third persons such as experts. These are called administrative trial subjects who have certain procedural rights and duties and that by their actions affect the course, development and completion of the trial.

Other persons such as interpreters (translators), witnesses and experts participate in the administrative adjudication. But these, with their participation, do not affect in the development of judgment but only assist the activity of other participants in the notice of facts or their technical or scientific knowledge. Therefore they are not subject to judgment (A.Lamani, "Civil Procedure of People's Republic of Albania", Tirana, 1962, p.27.).

In terminology and analogy of procedural law, specifically referring to Article 15 of Law no. 49/2012 "On the organization and functioning of Administrative Courts and adjudication of administrative disputes" (Law no. 49/2012 "On the organization and functioning of Administrative Courts and adjudication of administrative disputes in Albania).

\section{Administrative Court}

The Court as a subject of administrative procedural legal relation has a special and foremost position because it is the only one that has the authority to resolve an administrative issue by means of a final decision (Adv.N.Uka, Adv.J.Brati, "Magistracy \& Advocacy "," ILARI "P.F., Tirana, 2012, p.454).

The Court has an organizational and managing role throughout the administrative judicial process, even without the court there could not be thought the development and completion of the process, and has a passive role during the trial. The Court as a subject has rights and duties established in a concrete administrative judicial proceeding. The main task of the court is to review and give a decision on any issue submitted for consideration on the grounds that the law is absent, is not complete, contains contradictions or is unclear (Article 1 second paragraph of the Code of Civil Procedure).

In addition, the court has duties of procedural and legal character as it is forced to express to all inquiries and claims of the parties and only within the limits of what is required. It should support its decision only in the facts that are presented by the parties at the trial as well as to conduct a full and comprehensive investigation, which shows a nonactive role of the court, but much more as a duty that it will give the parties the opportunity to demonstrate their research and proposals.

There have been a great number of cases where this principle is not understood correctly being confused with the issue of jurisdiction and competence.

In case the law is absent or has a legal vacuum which means that for a certain issue there is not a legal procedural provision that provides its review by the court and the case does not fall under the jurisdiction of other bodies, court is obliged to accept the case for consideration and give a decision based precisely in this principle as well as in other general principle norms which regulate other analogous issues.

The Court is subject to judicial process and as such it has the right and duty to take measures for the proper conduct of the judicial process, to ask by the participating parties the conduct of procedural actions, to take measures to ensure the evidence when the parties are unable to be presented as well as to delegate responsibility to the party who try to prevent the normal development of the process or its extension and complexity.

The Court shall exercise judicial power independently, being a constitutional body.

Article 90 first paragraph of the Code of Civil Procedure, which states: "Parties to an administrative trial are physical or legal persons on behalf of or against whom the judgment is carried out" (Article 90 first paragraph of the Code of Civil Procedure).

Such an argument and definition implies that the parties are subject to administrative procedural legal relations because without them there can be no administrative process and with the quality of subjects they enjoy rights and are charged with several duties.

They are obliged to conduct procedural actions in the form required by law, to maintain the respect that dictates the judicial process; they are not permitted to use inappropriate or offensive expressions because otherwise there are provided sanctions for violation of this prohibition. The suit itself must meet certain requirements provided by administrative law because otherwise the court gives time for completion of the shortcoming and in case it does not meet the deadline then it is entitled to return the claim (Floqi, Kristo, "Administration or Dominion Law" The general part, "Vlora" Printing House, 1923).

The party that is addressed with lawsuit against one or more natural or legal persons seeking protection of the rights or legitimate interests that claims to be denied or violated, powering the court which in turn is obliged to be limited to review only issues raised by the parties. 
The person who is addressed to the court to request the recognition or restoration of a right claiming that it is denied or violated by an administrative body which he summons regularly before the court, is called plaintiff. While another person summoned to court to answer that according to the claim of the person who summons him in the court has denied or violated his right, is called defendant. Both the plaintiff and the defendant are called party or litigant, or litigant party (A.Lamani, "Civil Procedure of People's Republic of Albania ", Tirana, 1962, p.29.)

In those cases where the issue may be of interest to other people who do not participate in the process, then in order to avoid the concern and recurrence of the trial process, it have been given the possibility of intervention in this process to the third persons, as a party. The third person may interfere being filed against both parties or by joining one party against the other and thus acquiring the quality of the administrative procedural legal relation. This happens only when he has his legitimate interest to protect because otherwise is not acceptable or may not be summoned.

Parties are characterized by the fact that:

- Trial is conducted on their behalf and against them in relation to the protection of their administrative rights;

- The power of judicial decision in regard to the conflict on the administrative rights lies on them;

- They as a rule have in charge the court costs. (A.Lamani, "Civil Procedure of People's Republic of Albania", Tirana 1962 p.30.)

\section{Subsidiary Subjects that are Part of the Administrative Procedural Legal Relations}

Subjects participating in a legal relation of an administrative judicial process, at the request of the parties or summoned by the court as subjects that have an interest in the issue, are the ones who do not assume the consequences of the process but provide their assistance to the parties and the court to realization of the process and its completion, where can be mentioned the summons of third persons, the summons as interested party of the state advocacy, as well as subjects that contribute to the judicial process.

In addition, as such subjects, we may also mention the judicial secretary who keeps minutes of court, witnesses, experts, interpreters (translators) etc. The legal process is broad and as such it can affect different areas of life that require specialized opinion of experts of the respective field.

The expert is an indispensable subject in ownership conflicts, or in cases when party to the process are persons who do not speak Albanian or we have acts that are not in Albanian and in this case is necessarily required the presence of a court interpreter for normal trial development and a complete and versatile investigation of the case under trial.

These actors enter into procedural relations, since their actions are conditioned by the procedures and assist the judicial process and its subjects but are not subject to the process.

\section{The Content of Administrative Procedural Legal Relation}

The content of administrative procedural legal relation in itself constitute the entirety of the rights and duties of the subjects of these relations and the relations between the rights and duties that arise during the course of the administrative process. The exercise of these rights and the fulfillment of tasks in the administrative process ensures the development of a fair trial.

The litigants in administrative adjudication have certain procedural rights and duties, procedural duties are provided in generic way and only a few of them in particular (A.Lamani, "Civil Procedure of People's Republic of Albania", Tirana 1962 p.36.)

Administrative procedural rights are the possibility that the law recognizes to the subjects of the administrative procedural legal relation to perform administrative procedural actions according to legal provisions such as the right of plaintiffs to sue etc., the right of the defendant to prove the legality of administrative acts, administrative contract and other administrative action, issued not with the plaintiff's request as well as the facts that he has filed and has put in activity underlying objected in court; to prove the legality of the actions in labor relations, from which the dispute has arisen, subject to judgment; In other cases, the party has the obligation to prove the facts, in which bases its claim.

But even in these cases, the court, and mainly, with an interim decision may decide to pass the burden of proof to the public body, when there is reasonable suspicion, based on the evidence in writing, proving that the public body conceals or does not intentionally present facts and evidence relevant to the resolution of the dispute. This decision is appealed together with the final decision, etc..

Administrative procedural duties are those procedural actions that the subjects of the procedural legal relation are obliged to perform, for example the court is required to resolve the issue with the court decision, the plaintiff is required to complete the shortcomings of the lawsuit, the parties are obliged to make known to each other the evidence on which 
they support their claims etc. (Çomo, Jani, "The Administrative Law of the Republic of Albania" The third book, published 1983).

In order to understand the content of the administrative procedural legal relation, it should be clarified the distinction between administrative procedural legal relation subjects and the subjects of judicial administrative process.

Subjects of administrative procedural legal relation are the court, the plaintiff, the defendant, third persons that interfere or are summoned in the process, judicial secretary, witnesses, experts, interpreters (translators), other courts that perform actions by delegation, the bailiff who participates in the execution as other persons participating in this stage. Whereas subjects of administrative judicial process are those who assume the consequences of the process that are the court and the parties. Subjects of the administrative procedural legal relation are all those who because of the law or circumstances, enter the procedural relations with each other and with the court, realize administrative procedural actions, while the subjects of the trial unlike the subsidiary subjects undertake and realize the consequences of the trial materialized by court decision.

The administrative judicial process is part of the administrative procedural legal relation. Its subjects are part of this relation; whereas, the administrative procedural legal relation is a field larger than the judicial process and includes the latter within it. Therefore not all subjects of the relation are subjects of the process also.

\section{Subjects who Participate in Legal-Administrative Judicial Process and Procedural Operations of the Judicial Process Subjects}

Administrative judicial process is realized between one, two or more persons who are placed opposite each other in front of a particular subject in charge of resolution of an administrative issue of a final decision. In order to have an administrative process must necessarily be three subjects if the trial is conducted with two parties.

The administrative judicial process has as its party the plaintiff, the defendant (the administrative body) and the socalled third persons who voluntarily intervene to protect their interests or who are obliged to intervene because they are a guarantee for the defendant (Adv.N.Uka, Adv.J.Brati "Magistracy \& Advocacy" "ILARI" P.F. Tirana, 2012, p.551.)

The plaintiff in the administrative judicial process is the person who is addressed to the court with a lawsuit to seek the recognition or the restore of a right that claims to have been infringed or denied by a public body which by lawsuit he summons it in court considering it as respondent.

The defendant is summoned by the plaintiff in his claim, while the court as a state body has a unique position in the process, because it is the only body that reviews an administrative issue and gives the final decision and which is determined despite the will of the parties. In the judicial process they are indispensable subjects because without them there is no process, but part of the process can become even the third persons who may intervene or can be summoned as such, if together with the object of the claim they have the interests as subject to review.

Third persons can interfere with researches against the parties in the process or can join one party against the other party. All these participants perform procedural actions which constitute the content of the administrative process. The parties and other subjects participating to protect their interests perform procedural actions in order that the court resolve disputes between them. Concrete procedural consequences arise by the performance or nonperformance of these actions. Procedural actions of the parties are regulated by law.

\section{Conclusions}

The Administrative Court has a different position because its duty is the final solution of the case under consideration, to carry out certain procedural actions to resolve the issue which are generally mandatory for participants in the process.

Court procedural actions should be distinguished from procedural actions of preparatory character from those of decisive character. Preparatory actions are intended to better prepare the trial process as it helps in the quick resolution of the issue. Whereas in the decisive procedural actions the court aims to resolve a caliming issue.

Procedural actions performed by the parties or the third persons differ by deadline conditional actions and by revocable or irrevocable actions.

In procedural actions with deadline, the disrespect of this deadline entails the loss of the right to perform these actions (Floqi, Kristo, "Administration or Dominion Law" The general part, "Vlora" Printing House, 1923).

Revocable procedural actions bring indirect effects such as complaint, lawsuit etc. It is determined that the waiver of the claim or complaint can be made at any time up to the moment of issuing a judgment with final force and effect. Irrevocable procedural actions are those with direct effect because in the moment of their birth comes the procedural consequences provided by law for example revocation of the waiver of appeal cannot happen. 
Whereas, when the party files an appeal against the final decision the action is revocable because the party may revoke to waive the appeal but the action of surrender is irrevocable, it cannot be waived by it because the legal process is closed and the consequences come immediately. The available procedural actions are generally irrevocable, in which the party that performs them worsens its own position, because if the possibility of revocation would have been recognized it would as a consequence give rise to uncertainty about the position of the other party and endless procrastination of the process.

\section{References}

Benvenuti, F., "Funzione amministrativa, procedimento, processo", Revista Trimestrale del Diritto Publico, 1952

Floqi, K., "Administration or Dominion Law" The general part, "Vlora" Printing House, 1923, Vlora.

Galligan, Discretionary powers, viti 1996

Lamani, A, (1962), "Civil Procedure of People's Republic of Albania", Tirana.

Peter Cane, An Introduction to administrative law, viti 1997

Presidential Decree no. 1501, dated May 29, 1996 "On the Establishment of Administrative Sections, Commercial and Family at the District Courts"

Uka, N (Adv.), Brati, J, (Adv.), 2012, "Magistracy \& Advocacy" "ILARI" P.F. Tirana.

\section{Laws}

Administrative Procedure Code of the Republic of Albania, 2009

Civil Procedure Code of the Republic of Albania, 2008

Constitution of the Republic of Albania, Law no. 8417, dated 21.10.1998, Official Journal, no. 28, dated 12.07.1998.

Law no. 49/2012 "On the organization and functioning of Administrative Courts and adjudication of administrative disputes in Albania

Recommendation for Judicial Review of Administrative Acts, 15 December 2004 the Council of Ministers of the European Council

\section{Web site}

Website of Tirana's District Court.

Official website of the European Mission of Assistance to the Albanian Justice System

Official website of the Supreme Court of Albania: www.gjykataelarte.gov.al

http// www.euralius.org.al 